Guest Editorial, part of a Special Feature on Law and Social-Ecological Resilience, Part II, Contributions from Law for

Social-Ecological Resilience Symposium Stockholm, Sweden, 2010

\title{
Introduction: Where in Law is Social-Ecological Resilience?
}

\author{
Jonas Ebbesson $^{1}$ and Ellen Hey ${ }^{2,3}$
}

Key Words: EU; international law; justice; law; property; public participation; resilience

\section{INTRODUCTION: WHERE IN LAW IS SOCIAL- ECOLOGICAL RESILIENCE?}

How does resilience research matter for legal scholarship and law, and the other way around, how does law and legal scholarship matter for resilience research and for socialecological resilience? Resilience research, besides describing and theorizing how social-ecological systems work, seeks to identify factors that enhance the resilience of such systems or reduce it for the sake of transformations into new development paths. It thus has an essential normative dimension and through that dimension intends to influence policy to develop in more resilient ways. Law also seeks to pursue normative ends related to concepts such as justice and the rule of law. By way of its concepts, rules, procedures, and institutions, law seeks to protect certain societal values such as equality before the law and nondiscrimination. In addition, law is used as an instrument to achieve various environmental and social objectives such as the protection of habitats, the prohibition to market and use hazardous chemicals, or the construction of buildings to withstand floods and earthquakes. However, these same concepts, rules, procedures, and institutions also affect society's capacity to address change, complexity, and adaptation. We suggest that it is therefore important for resilience researchers to engage with law and for legal researchers to engage with resilience thinking if more sustainable societal structures are to be attained.

How, then, does law fit into social-ecological resilience thinking? Does it promote or reduce persistence in the face of change so as to buffer capacity and withstand shocks? Does it foster or bar adaptability and the capacity of people to manage resilience through collective action? Does it enhance or block transformability, i.e., the capacity of people in a social-ecological system to create new ecological, political, social, or economic conditions and thereby override existing systems (Folke et al. 2010)? Is it at all possible to make general statements about law and resilience?

We think it is. Legal structures, principles, and processes, as well as core concepts of the rule of law, impinge on the capacity of societies to manage ecosystems, withstand environmental degradation as well as economic shocks, and rebuild and renew themselves afterwards. Law thus affects the resilience of social-ecological systems, positively or negatively, and it may more or less adequately match important notions of environmental and health governance and ecosystems management, such as:

- dealing with uncertainties and surprises,

- sustaining and absorbing stress, external interference, and complex change, whether human-made or not,

- managing nonlinear effects and tipping points, and

- adapting to new circumstances.

However, to agree that law is one of many factors that impinge on the capacity of social-ecological systems to address these concerns is only the first step. It is quite another step to examine how it affects social-ecological systems, and yet another step to seek to identify legal features that can promote resilient structures. Resilience literature, while not homogenous, has identified a number of factors that foster our capacity to sustainably engage with social-ecological systems (e.g., Folke 2006, Walter and Salt 2006, Ebbesson 2010, Biggs et al. 2012). Among these factors are:

- flexibility in social systems and institutions to deal with change

- openness of institutions so as to provide for extensive participation

- effective multi-level governance

- social structures that promote learning and adaptability without limiting options for future development

All these factors may be affected, positively or negatively, by legal structures, concepts, and institutions. Some examples may serve to illustrate this point. While the notion of the rule of law may hamper the flexibility to adapt to change, the rule of law and legal certainty also foster trust and help to buffer capacity to persist, adapt, and transform, when required. The openness of social institutions and the opportunities for participation may be supported as well as countered by legal structures. The scope for multilevel governance depends on, for example, the states' internal division of power between local, regional, and central units, and on the opportunities for nonstate actors (civil society and private sector) to participate in international treaty regimes. The use of a permit system,

${ }^{1}$ Department of Law, Stockholm University, ${ }^{2}$ Erasmus School of Law, Erasmus University Rotterdam, ${ }^{3}$ School of Law, University of New South Wales, Sydney 
which is a common element of environmental control in numerous jurisdictions, may reduce or enhance the ability of industrial activities to adapt to change. And so on.

By requiring the participation of those involved in or affected by a certain activity, law can contribute to making socialecological systems more resilient or to supporting transformations. Participation, we suggest, offers opportunities to foster learning and change. On the one hand, law may require that the private sector participates in addressing environmental concerns, with property rights offering a basis for such a requirement. On the other hand, participatory processes may require or allow actors with different interests to engage with each other, such as in the preparation of environmental impact assessments or ultimately before a court of law where decisions of often powerful public and private actors can be challenged (Ebbesson 2010).

Law and resilience relate to each other in two distinct ways. The first aspect has been described, i.e., how law influences the resilience of social-ecological systems. The other aspect refers to the resilience of law itself: how legal concepts, principles, and processes persist in the face of change, and how law maintains its structure or adapts to new circumstances. While more research is required to see if and how the panarchy model, frequently referred to in resilience literature (e.g., Walter and Salt 2006), can be applied to law, we suggest that law generally is among the slower drivers of change in the panarchy of nested adaptive cycles, which are central to social-ecological thinking. It may also well be the case that as law moves from the local level to the national, regional, and international levels, law itself, due to the enhanced complexity of decision-making, becomes more resilient to change, and its capacity to address change, complexity, and adaptation slows down.

The resilience of law can be good or bad for the resilience of social-ecological systems. Law's resilience to change is based on socially valued concepts such as trust, legitimacy, and legal certainty. For international law, these concepts translate into, for example, the conclusion of multilateral agreements that are binding for the state parties (and the European Union [EU]) that consent to be bound by them. These agreements, while slow in process, create trust and define what is expected, allowed, and prohibited. Ultimately, legal certainty serves to address the arbitrary exercise of power in both public and private relationships. Think of a government agency issuing permits for activities that may have environmental effects or of contractual relations involving the transfer of property. Law in each of these cases seeks to limit discretion by imposing certain rules of conduct that prevent, respectively, the agency from issuing permits based on, for example, race, and the seller from not disclosing to the buyer that the land they are transferring is designated for nature conservation purposes and cannot be used for agricultural activities. By doing so, law seeks to protect societal values that may well foster social- ecological resilience by enhancing cohesion in a society and thus facilitating its capacity to accommodate change. Yet, these characteristics of law may also hamper necessary changes and support unsustainable business practices and inflexible governance, and unfair decision-making with devastating effects on health and the environment.

What this illustrates is that in linking legal and resilience research, our concern should be with the normative values that are present in each of these domains. In addition, our engagement should not only be with environmental and health law, but with a variety of areas of law, including property law, administrative law, and human rights law, and at a variety of levels from the local to the global.

In November 2010, the Stockholm Environmental Law and Policy Centre and the Stockholm Resilience Centre, both at Stockholm University, organized a conference entitled Law for Social-Ecological Resilience (www.juridicum.su.se/ resilience). The Stockholm conference provided an opportunity for lawyers and resilience researches to engage with and learn from each other. The papers in this Special Feature on Law and Social-Ecological Resilience by Richard Barnes, Barbara Cosens, Margarita Pieraccini, and the coauthored paper by Jurriën Hamer, Andrea Keessen, Marleen van Rijswick, and Mark Wiering find their origin in this conference.

Focusing on the four contributions that emerged from the Stockholm conference, we note the following. First, as with the other contributions to this issue, they illustrate a willingness on the part of legal researchers to engage with resilience thinking and research. Secondly, they illustrate the need for resilience researchers to engage with law as one of the factors that affects societies' capacity to engage with change.

Richard Barnes' contribution illustrates the potential of property rights to accommodate social-ecological resilience through the creation of transferable environmental allowances to foster participation of private actors in regimes that seek to attain more sustainable ways of production. Property regimes generally combine several types of property, ranging from individual private property to forms of collective holding. Barnes shows how property rights, traditionally in the domain of national law, are also affected, indirectly or directly, by European Union and international law, for example, through, respectively, the EU Marine Strategy Directive and human rights law. He also illustrates that property rights per se do not discourage or encourage social-ecological resilience. Instead, public regulation and court procedures can serve to attain the normative aims of resilience research, i.e., to sustain the capacity and flexibility to deal with change and surprise, and to continue to develop. Courts, in particular, can do this also "without fundamentally changing the structure of a system." Barnes argues that private property is an enduring institution, 
capable of operating at large scales through market-based economies. Markets generally mean that private property is socially responsive, but Barnes emphasizes that there are occasions when it can be very resistant to change. It is best suited to narrowly drawn resources rather than large complex resource systems, and it encourages protection of and investment in resources. In contrast, Barnes continues, community-based holdings may be better suited to complex resource regimes at local levels. Although less socially adaptive, they may be better suited to changes in ecological systems because of their greater sensitivity to the natural constraints on resource use. Barnes concludes that no single type of property is a panacea.

Barbara Cosens, in her contribution, uses the concept of legitimacy to highlight the need to include in resilience research a responsiveness to the social systems involved. She focuses on administrative decision-making, which encapsulates most of environmental decision-making, and points to the manner in which legitimacy enhancing processes, in which participation plays a prominent role, can be introduced in such decision-making. She argues that including legitimizing procedures in decision-making, including various forms of participation, is important because they will allow for more adaptive approaches and are more likely to engender public acceptance. She also points out that these processes should be in place not only at various levels of governance but also across scales of governance. The latter is particularly important because the effects of legitimizing factors are often lost in cross-scale decision-making. She refers to the example of a decision to build in a river floodplain. While that decision may have been made with local participation, it may not have been made with the participation of those living across the border who might, as a result of the building activity, have to invest in water storage facilities due to the floodplain having lost its function as a water storage area. Cosens concludes that the recognition of the complexity in the social-ecological system, and of the complete dependence of the human race on the ability of the ecological system to serve it, requires reform of the administrative state to allow society to responsibly respond to the challenge of managing human interaction with ecosystems.

Jurriën Hamer, Andrea Keessen, Marleen van Rijswick and Mark Wiering argue that the introduction of policies to promote resilience will involve the making of normative choices that are informed by political preferences regarding how we assess the public interest, public and private responsibilities, and individual rights. They further argue that such choices should be made explicit and should be the subject of public debate in order to ensure that the choices made are regarded as legitimate. Their contentions are illustrated by five case studies related to the introduction of climate change adaptation policies in the Netherlands. These case studies reveal that climate change adaptation policies aimed at promoting resilience involve debate about what type of society and the type of resilience measures we wish to further. For example, do we wish to shift (part of) the responsibility for flood control to the private sector? Both public and private responsibility for flood control might lead to a resilient system, but which one we choose depends on political preference, and those preferences, the article suggests, can be determined only through public participation.

Margherita Pieraccini points to the need to enquire beyond the harmonious interaction of various legal systems that are applicable to a resilient common pool resource because such arrangements may shield questionable power relations that serve to exclude certain actors from participation in the common pool. Her case study of an alpine common pool resource in the Regole d' Ampezzo, in northern Italy, illustrates that synergy between macro and micro levels of regulation and between customary, property, and environmental law can serve to generate a resilient management system for the common resource in question. However, as she points out, we need to enquire deeper and ask who benefits and who loses as a result of these arrangements. Drawing on Foucault's powersubject nexuses, she illustrates that harmonic legal pluralism in the Regole, while promoting social-ecological resilience, also has served to sustain gender inequalities, which bar women from inheriting rights and participating in decisionmaking regarding the common pool. Therefore, she argues, the analysis of power relations at the micro level needs to highlight "strategies of struggle", and a legal study of the resilience of common pool resources can benefit from a politicized version of legal pluralism.

We add that participatory requirements in European Union or international law may also have a role to play. An example of such a mechanism is the Aarhus Convention on Access to Information, Public Participation in Decision-Making and Access to Justice in Environmental Matters. Its compliance mechanism enables individuals and groups in society to submit claims of noncompliance with standards regarding transparency, participation, and access to justice against a party to the convention. In this case, a participatory mechanism at the international level may induce change at the national and European Union levels, the EU also being a party to the Aarhus Convention participation (Koester 2011). The potential of access to justice as a mechanism for individuals and groups in society to effect changes in society from below is also illustrated by the case law of the European Court of Human Rights regarding the right to fair trial and the right to respect for private and family life, as proscribed by the European Convention on Human Rights, to encompass environmental considerations (García San José 2005).

Likewise, the requirement in European Union directives, such as the Water Framework Directive and the Marine Strategy Framework Directive, that policies be adopted with the participation of the public have served the adoption of 
participatory process within member states but also within international river basin and regional seas commissions, which in Europe play an important role in implementing the Water Framework Directive (Hey 2009). Another example of how law may foster change through participation and across scales is the World Bank Inspection Panel (WBIP), established by the World Bank in 1993. The WBIP enables individuals and groups affected by projects supported by the bank to submit complaints against the bank. The WBIP has resulted in World Bank staff becoming more sensitive to the interests of the people on the ground (Naudé Fourie 2009). We suggest that these mechanisms can facilitate cross-scale interactions, thus enabling the more flexible local level to induce change at the slower regional or international levels. We also suggest that these mechanisms serve to legitimize cross-scale interactions and support social-ecological resilience by enhancing the openness of institutions, facilitating interaction between the various levels of multi-level governance, and promoting crossscale learning.

We conclude this introduction by addressing what we think might be fruitful venues for further research at the crossroad of law and resilience. First, we suggest that social-ecological resilience research must develop to further include law in its considerations. We propose the development of research projects that involve both legal and resilience researchers. Second, legal researchers might consider carefully mapping systemic traits of legal systems into social-ecological resilience research. Barnes' and Cosens' contributions offer examples of this approach. Third, case studies that illustrate how policy and law to promote resilience can work to hide political choices are illuminating and essential if we wish to understand how legitimate social-ecological resilient institutions might be attained. The contributions by Hamer et al. and Pieraccini point to precisely this problem, albeit in very different ways. Pieraccini, in particular, points us to the fact that we must remain critical of what are resilient arrangements by most accounts, for they may, if analyzed through another lens, be revealed to sustain relations of inequality. Aiming at social-ecological resilience must not prevent us from including other values, such as equality before the law and nondiscrimination. These are values that law should seek to protect, both substantively and procedurally, through, among other things, public participation.

Responses to this article can be read online at:

http://www.ecologyandsociety.org/issues/responses. $\mathrm{php/5750}$

\section{Acknowledgments:}

Jonas Ebbesson, Dean of the Faculty of Law Stockholm University, Professor of Environmental Law, Director of
Stockholm Environmental Law and Policy Centre, and Chair of the Aarhus Convention Compliance Committee. Ellen Hey, Professor of Public International Law. Erasmus School of Law, Erasmus University Rotterdam, Visiting Professorial Fellow, School of Law, University of New South Wales, Sydney, and a member of the Aarhus Compliance Committee. Hey acknowledges the support of Next Generation Infrastructures http://www.nextgenerationinfrastructures.eu/.

\section{LITERATURE CITED}

Biggs, R., M. Schlüter, D. Biggs, E. L. Bohensky, S. BurnSilver, G. Cundill, V. Dakos, T. M. Daw, L. S. Evans, K. Kotschy, A. M. Leitch, C. Meek, A. Quinlan, C. RaudseppHearne, M. D. Robards, M. L. Schoon, L. Schultz, and P. C. West. 2012. Toward principles for enhancing the resilience of ecosystem services. Annual Review of Environment and Resources 37:421-448.

Ebbesson, J. 2010. The rule of law in governance of complex socio-ecological changes. Global Environmental Change 20:414-422. http://dx.doi.org/10.1016/j.gloenvcha.2009.10.009

Folke, C. 2006. Resilience: the emergence of a perspective for social-ecological systems analyses. Global Environmental Change 16:253-267. http://dx.doi.org/10.1016/j.

gloenvcha.2006.04.002

Folke, C., S. R. Carpenter, B. H. Walker, M. Scheffer, F. S. Chapin III, and J. Rockström. 2010. Resilience thinking: integrating resilience, adaptability and transformability. Ecology and Society 15(4):20. [online] URL: http://www. ecologyandsociety.org/vol15/iss4/art20/

García San José, D. 2005. Environmental protection and the European Convention on Human Rights. [online] URL: http:// book.coe.int/EN/ficheouvrage.php?PAGEID=36\&lang= EN\&produit aliasid $=1883$

Hey, E. 2009. Multi-dimensional public governance arrangements for the protection of the transboundary aquatic environment in the European Union: the changing interplay between European and public international law. International Organizations Law Review 6(1):191-223. http://dx.doi. org/10.1163/157237409X464242

Koester, V. 2011. The compliance mechanism-outcomes and stocktaking. Environmental Policy and Law 41(4-5):196205.

Naudé Fourie, A. 2009. The World Bank Inspection Panel and quasi-judicial oversight: in search of the "judicial spirit" in public international law. Eleven International Publishing, Utrecht, The Netherlands.

Walter, B. H., and D. Salt. 2006. Resilience thinking: sustaining ecosystems and people in a changing world. Island Press, Washington, D.C., USA. 